\title{
USING XENIA IN THE BREEDING OF RYE HYBRIDS
}

\author{
LECHOSŁAW GROCHOWSKI ${ }^{1}$, JAN KACZMAREK ${ }^{2}$, WŁADYSŁAW KADŁUBIEC ${ }^{2}$, HENRYK BUJAK ${ }^{2}$ \\ ${ }^{1}$ Plant Breeding and Acclimatization Institute, Experimental Station, \\ 63-743 Smolice, Poland \\ ${ }^{2}$ Department of Plant Breeding and Seed Production, Agricultural University, \\ Cybulskiego 34, 50-205 Wrocław, Poland
}

(Received: October 14, 1994. Accepted: April 19, 1995)

\begin{abstract}
The object of research were: hybrid grains $F_{1}$ of winter rye resulting from the topcross of nine yellowseed inbred lines with two testers Madar and Krótka I, and six hybrids $F_{1}$ of spring rye resulting from topcross of six Turkish yellowseed populations with the tester SMH-02. The aim of the analysis was to confirm the degree of crossing ability and the effect of xenia of 1000 grains weight. The possibility to breed initial materials characterized by a high combining ability by means of xenia was stated. Xenia of 1000 grains weight allows to elaborate a new technology of hybrid seed production of rye.
\end{abstract}

KEY WORDS: rye, xenia, hybrid breeding, open pollination.

\section{INTRODUCTION}

Xenia is a phenomenon which enables to recognize the hybrid character of the seeds of xenogamical plants, on the basis of their phenotypical features (colour, shape, size) resulting from the direct influence of the pollens genotype on the germ or the seeds endosperm (Focke 1891). From the given above definition it results that in crossing plants in which the paternal form has got the dominant genes, it is possible to recognize among others, hybrid seeds, on a maternal plant. This phenomenon was observed in maize a long time ago (Waller 1916). Today xenia is used to distinguish haploid seeds, originating from parthenogenesis, because they do not have a trait typical for the paternal form (Roux 1993).

V. Rumker (1909) was the first to study the colour of seeds in rye. After crossing green and yellow seed forms he found the green colour as dominant, determined by one pair of genes. The next researchers who examined xenia were: Czechowicz (1929), Kobyljanskij (1989), Plarre, Vettel (1961), Cecot (1953), Grochowski $(1990,1992,1994)$. In the years 1985-1989 Grochowski selected many lines with yellow seeds which revealed a good combining ability (Grochowski 1990, 1992, 1994). Green hybrid seeds developed on yellow seed plants are the result of crossing with a foreign pollen and are characterized by a higher weight of single kernels.

The phenomenon of xenia provides new possibilities in the breeding of rye hybrids. Till now, the hybrid cultivars in rye have been bred on the basis of cytoplasmic male sterility (Geiger 1982, 1985, Łapiński 1975, Madej 1975). This method is very expensive and complex in the breeding process.

The occurrence of double xenia: of the first - qualitative conditioned by the gene marker (Fig. 1) and of the second quantitative -, e.g. of the weight of the single seed makes one of the new possibilities of a practical use of xenia effect in rye. Differences in physical properties of the seeds bred from hybridization and self-pollination enable the segregation and rejection of self-pollinates from the hybrids by means of sorting machines of Sortex type or vibration tables. The yellow colour of a seed-coat allows to estimate the efficiency of the technology of sorting seeds.

Having inbred lines of winter rye and a population of spring rye, the task was set to test the quantitative and qualitative xenia effect. The intention was to test the degree of open pollination and the possibility of using xenia in heterosis breeding instead of cytoplasmic male sterility.

\section{MATERIAL AND METHODS}

The objects of the investigation were:

a) nine lines of winter rye with yellow grain colour and 1000 grains weight (TKW) from 23,1 to $29,8 \mathrm{~g}$.,

b) six forms of spring rye with yellow grain coming from Turkey with 1000 grain weight 29,0 to $34,0 \mathrm{~g}$.,

c) two testers of winter rye with green grain: Madar and Krótka I of 1000 grains weight between 33,0 and $35,0 \mathrm{~g}$.,

d) a tester of spring rye SMH-02, with green grain and 1000 grains weight $37,0 \mathrm{~g}$.

Yellow grain forms of winter and spring rye were subjected to free crossing in the topcross with testers. Nine lines of winter rye with yellow grain were sown in two topcross in which the cultivar Madar and the population of Krótka I were the testers. Turkish populations of spring rye were tested with their own form SMH-02. Topcross fields area of about $1000 \mathrm{~m}^{2}$ were 


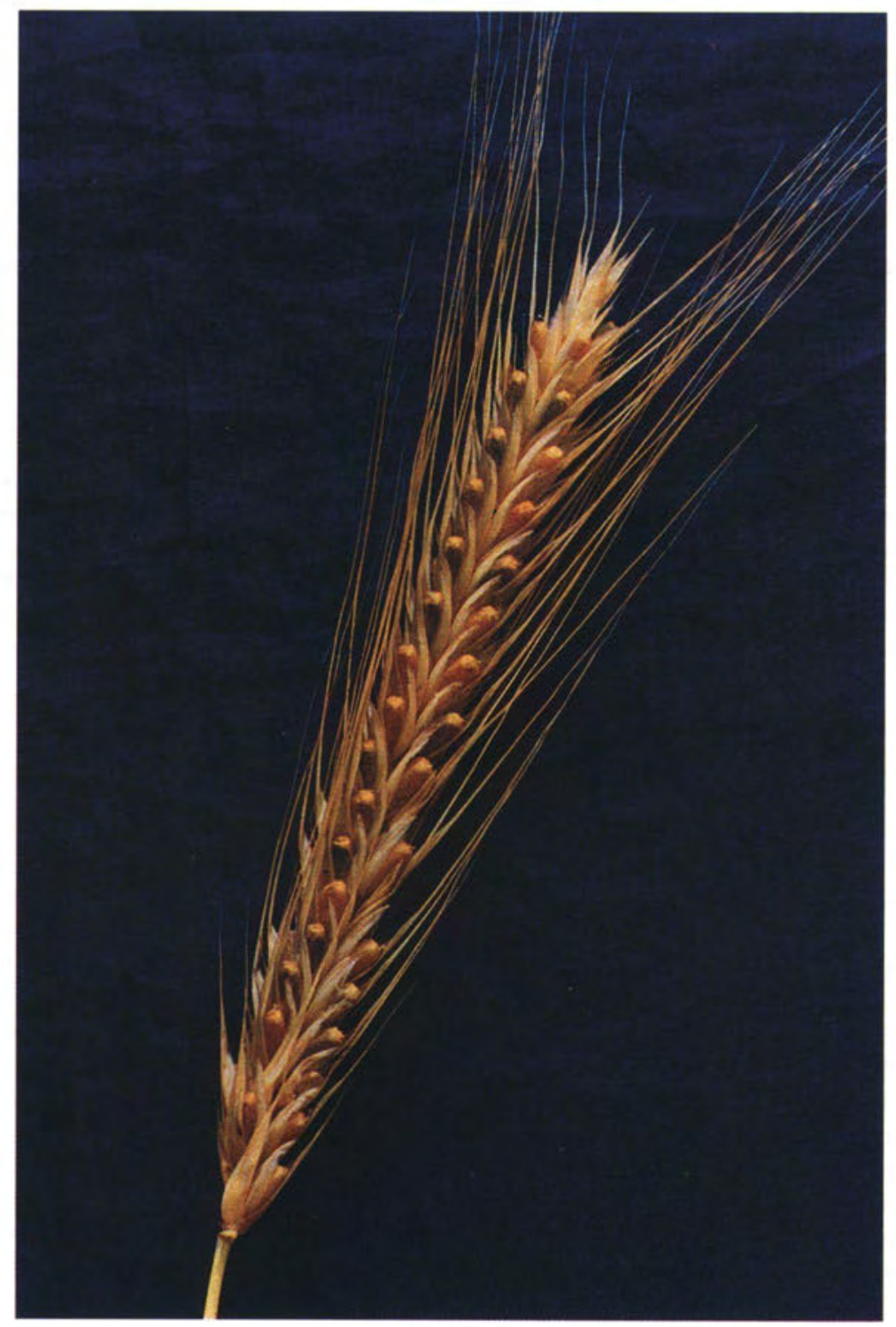

Fig. 1. The qualitative xenia in rye. The green seeds are results of hybridization - yellow seeds are results of pollination within the yellowseed form. 
TABLE 1. Effect of xenia hybrid grains of winter rye for 1000 grains weight to material lines ratio

\begin{tabular}{cccccc} 
Inbred lines & $\begin{array}{c}1000 \text { grains } \\
\text { weight } \\
\text { of the lines }\end{array}$ & $\begin{array}{c}\text { Madar } \\
1000 \text { grains } \\
\text { wight } \mathrm{F}_{1}\end{array}$ & $\begin{array}{c}\text { Percentage effect } \\
\text { of xenia }\end{array}$ & $\begin{array}{c}\text { Krótka I } \\
\text { 1000 grains } \\
\text { weight } \mathrm{F}_{1}\end{array}$ & $\begin{array}{c}\text { Percentage effect } \\
\text { of xenia }\end{array}$ \\
\hline 70474 & 28.99 & 32.27 & 111.3 & 31.11 & 107.4 \\
70545 & 23.14 & 26.06 & 112.6 & 25.71 & 11.1 \\
70551 & 27.37 & 28.82 & 105.3 & 28.12 & 102.7 \\
70556 & 27.68 & 29.74 & 107.4 & 30.47 & 110.1 \\
70610 & 29.40 & 30.16 & 102.6 & 31.58 & 107.4 \\
70617 & 27.39 & 29.16 & 106.5 & 29.59 & 107.8 \\
70620 & 26.25 & 29.90 & 113.9 & 28.58 & 104.4 \\
70621 & 28.56 & 33.29 & 116.6 & 31.21 & 115.0 \\
70677 & 29.80 & 29.77 & 94.9 & 34.28 & $108.3 \pm 1.1$ \\
\hline Mean & $27.62 \pm 0.64$ & $29.91 \pm 0.64$ & $107.9 \pm 2.1$ & $30.07 \pm 0.77$ &
\end{tabular}

TABLE 2. Effect of xenia hybrid grains of spring rye for 1000 grains weight to material forms ratio

\begin{tabular}{cccc}
\hline Mather forms & 1000 grains weight of lines & 1000 grains weight $F_{1}$ & Percentage effect of xenia \\
\hline TK $12342 / 67$ & 33.6 & 34.6 & 103,0 \\
TK $12568 / 67$ & 30.6 & 33.6 & 109,8 \\
TK $12863 / 67$ & 34.0 & 35.0 & 102,9 \\
TK $15594 / 68$ & 33.3 & 38.0 & 114,1 \\
TK 26334/68 & 29.0 & 31.0 & 106,9 \\
Local 12362/67 & 29.6 & 31.6 & 106,7 \\
\hline Mean & $31.7 \pm 0.8$ & $33.6 \pm 0.9$ & $107.2 \pm 1.6$ \\
\hline
\end{tabular}

sown in space and time isolation. Per two rows of the sown testers one row of the maternal form was sown. The testers were sown using a drill and the maternal forms by hand, both components in the same quantity of 300 grains $/ \mathrm{m}^{2}$. During harvest each of the maternal forms was gathered separately. After the harvest a sample containing about 5000 seeds of the maternal plants was taken from each hybrid combination. On the basis of xenia occurrence, each sample was sorted into parts of green (hybrid grain) and yellow (selfpollinates) colour of seeds cover. Then 1000 grains weight (TKW) in both the groups was compared. The percentage of green grain content in each sample determined the crossing ability of the particular maternal forms. Differences in 1000 grains weight of both the groups were found as a quantitative xenia effect.

\section{RESULTS}

\section{Quantitative xenia effect of 1000 grains weight}

Tables 1 and 2 present the results of estimation of xenia of 1000 hybrid grains weight in relation to the maternal forms of winter and spring rye. The xenia effect of a single seed weight in $F_{1}$ appears on the maternal plant in winter and spring forms (on the average 108.6\% and 107.3\%). The increment over $10 \%$ may have a practical meaning in seed production. From Tables 1 and 2 it results that it is possible to obtain this effect.

\section{Degree of open pollination}

Table 3 presents the results of open polination of nine lines with yellow grain with two testers: i.e., the cultivar Madar and the population Krótka I. From the outline data it results that the percentage of open pollination depends on maternal lines and on the tester, and fluctuates between 45.3 and $98.1 \%$. The average percent of open pollination for the cultivar Madar is 81.4 and for the population Krótka I $68.8 \%$. This evidences the differentiated reaction of maternal genotypes on the testers. Most interesting, according to open pollination are the lines 70621 and 70677 , which reached $98.1 \%$ and $93.9 \%$ respectivly with Madar pollination. The same lines pollinated with the form Krótka I indicate a low percent of open pollination. Lines 70551 and 70556 are also worth of notice. They reached a similar percent of open pollination with both of the pollinators. This comfirms their high general combining ability.

In spring rye (Table 4), in comparison to the winter forms, a low percent of open pollination was caused by the different time of flowering and by differences in plant height between maternal forms and the pollinator. The maternal forms bloomed earlier, were higher and susceptible to lodging. The pollinator SMH-02 was characterized by a later flowering, stiffness and a shorter stem.

Among 18 hybrids of winter rye and six of spring rye, in eight hybrids the xenia effect of 1000 grains weight was observed in 110.5 to $116.6 \%$. Particularly interesting is line 
TABLE 3. Open pollination of 9 inbred lines of winter rye with yellow grains by Madar and Krótka I testers. ZD Smolice 1992

\begin{tabular}{ccc}
\hline Inbred lines & \multicolumn{2}{c}{ Open pollination $(\%)$} \\
\cline { 2 - 3 } & Madar & Krótka I \\
\hline 70474 & 81.4 & 76.6 \\
70545 & 74.6 & 67.3 \\
70551 & 81.1 & 79.4 \\
70556 & 81.9 & 80.9 \\
70610 & 79.0 & 77.3 \\
70617 & 81.9 & 78.8 \\
70620 & 61.3 & 45.3 \\
70621 & 98.1 & 54.1 \\
70677 & 93.9 & 60.1 \\
\hline Mean & $81.4 \pm 3.3$ & $68.8 \pm 4.1$ \\
\hline
\end{tabular}

TABLE 4. Open polination of 6 forms of spring rye with yellow grains polinated SMH-02 tester. ZD Smolice 1993.

\begin{tabular}{lc} 
Forms & $\begin{array}{c}\text { Open pollination against } \\
\text { SMH-02 tester }(\%)\end{array}$ \\
\hline TK 12342/67 & 42.5 \\
TK 12568/67 & 45.4 \\
TK 12863/67 & 56.0 \\
TK 15594/68 & 42.0 \\
TK 26334/68 & 45.1 \\
Local 12362/67 & 37.2 \\
\hline Mean & \\
\hline
\end{tabular}

70621 which crossed with Madar reached $98.1 \%$ of open pollination and $116.6 \%$ of the xenia effect of 1000 grains weight.

\section{CONCLUSIONS}

1. The results of the investigation indicate that there is a real chance to breed materials with high combining ability. These materials can be useful for breeding of rye hybrids with the use of xenia.

2. It is possible to find parental forms with a higer combining ability and a high xenia effect of 1000 grains weight.

3. Xenia of 1000 grains weight allows to elaborate a new production technology of rye hybrid cultivars. The only condition is the possession a good sorting table or another machine which enables the segregation of hybrid seeds from maternal forms.

\section{ACKNOWLEDGEMENTS}

This work was financially supported by grant No. 5 S3010205 from the Polish Committee for Scientific Research (KBN).

\section{LITERATURE CITED}

CECOT J. 1953. Zagadnienie ziaren żółtych i zielonych u różnych odmian żyta z punktu widzenia wartości technologicznej. Cit. after: Reubenbauer T., Brej S.: Hodowla Roślin Zbożowych. Warszawa, PWRiL 1975.

FOCKE W.D. 1881. Die Pflanzenmischlinge, ein Beitrag zur Biologie der Gewachse Borntraeger. Cit. after: Rieger R., Michaelis A., Green M.M., Słownik terminów genetycznych. Warszawa, PWRiL 1974.

GEIGER H.H. 1982. Breeding methods in diploid rye (Secale cereale L.). Tag.-Ber. Akad. Landwirtsch. -Wiss. DDR: 305-332.

GEIGER H.H. 1985. Hybrid breeding in rye. Prac. Eucarpia Meet. Cereal Sect. of Rye, Svalov, Sweden: 237-266.

GROCHOWSKI L. 1990. Projekt programu wykorzystania ksenii w hodowli mieszańców żyta. Zesz. Problemowe IHAR, Hodowla zbóż: 165-172.

GROCHOWSKI L. 1992. Ksenia u żyta i jej wykorzystanie w hodowli mieszańców. Mat. Konferencji „Genetyka 2000”, XI Zjazd PTG, Kraków: 102.

GROCHOWSKI L., KACZMAREK J., KADŁUBIEC W., BUJAK H., 1994. Analiza zmienności i zdolności kombinacyjnych linii wsobnych żyta o żółtym ziarnie. Cz. I. Wstępna ocena wartości hodowlanej linii krzyżowanych z formami SMH 108 i Motto. Biuletyn IHAR 190: 3-8.

GROCHOWSKI L., KACZMAREK J., KADŁUBIEC W., BUJAK H., 1994. Analiza zmienności i zdolności kombinacyjnych linii wsobnych żyta o żółtym ziarnie. Cz. II. Ocena hodowlana linii krzyżowanych z populacją CHDM 16. Biuletyn IHAR 190: 9-15.

KOBYLJANSKIJ V.D., 1989. Kulturnaja flora SSSR. T. II. Czast 1: 161.

ŁAPINSKI M., 1975. Cytoplasmatic male sterility in interspecific rye hybrids. Hod. Rol. Aklim. i Nasien. 15/16: 415-420.

MADEJ L., 1975. Research male sterility in rye. Hod. Rol. Aklim. i Nasien. 19, 5/6: 421-422.

PLARRE W., VETTEL F., 1961. Testmethoden und Heterosiseffekte bei diploiden Winterroggen (Secale cereale L.). Z. Pflanzenzucht 46: 125-154.

ROUX S.R., DEIMLING S., GEIGER H.H., 1993. Parthenogenetische Haploideninduktion bei Mais. FSP Biotechnologie und Pflanzenzüchtung, Zeitschr. Universität Hohenheim.

RUMKER K., 1909. Korrelative Veränderung bei der Züchtung des Roggens nach Kornfarbe. Fühlings Landw. Ztg. H. 7.

WALLER A.E., 1916. Xenia in maize. Am. Bot. 22: 41-43. 


\section{WYKORZYSTANIE KSENII W HODOWLI MIESZAŃCOWEJ ŻYTA}

\section{STRESZCZENIE}

Obiektem badań było: ziarno mieszańcowe $\mathrm{F}_{1}$ żyta ozimego otrzymane z krzyżowania topcrossowego 9 żółtoziarnistych linii wsobnych żyta z 2 testerami Madar i Krótka I oraz 6 mieszańców $\mathrm{F}_{1}$ żyta jarego uzyskanych z krzyżowania Tureckich żółtoziarnistych populacji z testerem SMH-02. Przedmiotem analizy była ocena stopnia swobodnego przekrzyżowania oraz efekt ksenii masy 1000 ziaren. Na podstawie wyników badań stwierdzono, że możliwe jest wytworzenie materiałów wyjściowych charakteryzujących się wysoką zdolnością kombinacyjną, które mogą być użyte w hodowli odmian mieszańcowych żyta z wykorzystaniem zjawiska ksenii. Ksenia masy 1000 ziaren pozwala na opracowanie nowej technologii produkcji nasion heterozyjnych odmian żyta.

SŁOWA KLUCZOWE: żyto, ksenia, hodowla mieszańcowa, stopnie przepylenia. 